\author{
Руммо B.B.. \\ кандидат економічних наук, доцент \\ кафедра економічної теорії \\ та фрінансово-економічної безпеки \\ Одеська національна академія харчових технологій \\ вул. Канатна, 112, г. Одеса, Україна, 65039 \\ E-mail: etfeb@ukr.net \\ Рожнатова М.B. \\ аналітик з економічних питань ТОВ «Шабо» \\ Французький бульвар, 66/2, м. Одеса, Україна, 65044 \\ E-mail: rozhnatovamarina@mail.ru
}

\title{
ЗОВНІШНІ ТА ВНУТРІШНІ ЗАГРОЗИ ПРОДОВОЛЬЧОЇ БЕЗПЕКИ
}

\begin{abstract}
В статті виділено внутрішні та зовнішні загрози продовольчої безпеки України та запропоновані напрями забезпечення продовольчої безпеки країни. Охарактеризовані основні загрози продовольчої безпеки України, визначено особливості їх впливу.

Ключові слова: продовольча безпека, загроза, внутрішні загрози, зовнішні загрози, державне регулювання.
\end{abstract}

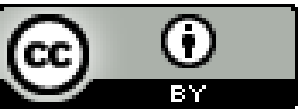

This work is licensed under a Creative Commons Attribution 4.0 International License http://creativecommons.org/licenses/by/4.0/
Постанова проблеми та її зв'язок $з$ важливими науковими та практичними задачами. Наслідки економічної кризи 2008-2009 р.р., що охопила національні та світові масштаби, відчули на собі всі українські підприємства, особливо, промислові, що призвело до скорочення обсягів виробництва у зв'язку із перенасиченням ринків збуту продукцією зарубіжних виробників. Зовнішні та внутрішні фактори, що впливають на послаблення економічної безпеки підприємств, здебільшого, взаємопов'язані між собою і окремо та в сукупності негативно впливають на фінансово-господарську діяльність підприємства внаслідок неправильного або несвоєчасного реагування на них, що може привести до його банкрутства. Тому одним 3 важливих напрямів боротьби 3 економічною кризою виступає формування системи діагностики корпоративної економічної безпеки промислових підприємств за всіма іiі складовими. В стратегію розвитку промислових підприємств для формування системи діагностики корпоративної економічної безпеки промислових підприємств необхідно обов'язково включити заходи, які дозволять мінімізувати зовнішні та внутрішні загрози його економічній безпеки [1, с. 2].

Аналіз останніх досліджень та публікацій: Продукти харчування є важливими та незамінними в життєдіяльності людини, тому розвиток харчової промисловості та виробництва сільськогосподарської продукції, що є основою харчування, виступає демографічним чинником. Цей чинник $є$ основним для забезпечення природних потреб людини, тому вивчення проблем продовольчої безпеки має завжди значну актуальність [2, с. 348].
Проблеми зовнішніх та внутрішніх загроз продовольчої безпеки знайшли відображення у працях таких вчених, як Паліги Н.Б., Світличної Ю.В., Мельник Л.Г., Кочеткова О.В., Гойчук О.І., Маркова P.В., Білої С.О., Русан В.М. та інших, але й сучасний момент функціонування підприємств промисловості $\epsilon$ актуальними та потребують подальших досліджень, особливо в частині передбачення зовнішніх та внутрішніх загроз продовольчої безпеки не тільки самого підприємства, але й країни в цілому.

Формування цілей дослідження. Метою статті є дослідження аспектів внутрішніх та зовнішніх загроз продовольчої безпеки в працях вчених та виділення їх 3 метою вдосконалення методів діагностики зовнішніх та внутрішніх загроз продовольчої безпеки та обгрунтування напрямів подальших досліджень.

Викладка основних результатів та їх обгрунтування. Проблема продовольчої безпеки завжди посідає провідне місце у безпеці кожної країни, оскільки є обов'язковою умовою та передумовою соціальної та економічної стабільності держави.

В економічній літературі поняття категорії «продовольча безпека» розглядається досить широко та $з$ точки зору різних підходів та аспектів. Так, наприклад:

- продовольча безпека - це ступінь забезпеченості населення країни екологічно чистими і корисними для здоров'я продуктами харчування вітчизняного виробництва за науково-обгрунтованими нормами і доступними цінами при збереженні і поліпшенні середовища проживання [3]; 
- продовольча безпека - це стан виробництва продуктів харчування в країні, що здатний повною мірою забезпечити потреби кожного члена суспільства в продовольстві належної якості за умови його збалансованості та доступності для кожного члена суспільства [19];

- продовольча безпека - офіційно прийняте у міжнародній практиці поняття, що використовується для характеристики стану продовольчого ринку країни або групи країн, а також світового ринку. Експерти Продовольчої та сільськогосподарської організації об'єднаних націй (FAO) пропонують продовольчу безпеку розглядати як забезпечення гарантованого доступу всіх жителів планети, країни, регіону до продовольства у будь-який час і обсягах, необхідних для забезпечення активного й здорового способу життя [4, с. 142$]$.

Існують певні загрози, які впливають на продовольчу безпеку любої країни, в тому числі й України. нашої. Загроза - це ступінь можливості реалізації небезпеки для розглянутого об'єкта. Загрози для конкретних об'єктів від реалізації небезпеки характеризуються можливістю впливу на них негативних факторів і заподіяння їм в результаті цієї шкоди. Загроза об'єкту від джерел небезпеки визначається їх відносним положенням у просторі і в часі (для стаці- онарних об'єктів тільки в просторі), розподілом напрямків вітру протягом року, характеристиками джерела небезпеки, досягнутим рівнем захищеності i стійкості об'єктів та іншими факторами.

Загроза являє й собою можливу небезпеку, заподіяння шкоди, наміру заподіяти фізичну шкоду і т.д. Визначення даного поняття можна трактувати порізному, але суть нього від цього не зміниться та але необхідно зауважити, що загроза - це злочинне діяння, за яке кривдник повинен понести покараня [6].

В Законі України «Про продовольчу безпеку України» відображено, що: загроза продовольчої безпеки - це наявні та потенційно можливі явища i чинники, що створюють небезпеку життєво важливим інтересам України [7].

Подолання саме загроз продовольчої безпеки, пов'язане 3 загальним економічним зростанням країни, поліпшенням іiі міжнародного іміджу, посиленням ролі при вирішенні загально - державних проблем [8].

Дослідження показало, що залежно від рівня ієрархії існують загрози зовнішнього і внутрішнього характеру, які значним чином впливають на погіршення стану продовольчої безпеки України (табл.1 та 2).

Зовнішні загрози продовольчої безпеки [9]

\begin{tabular}{|c|c|}
\hline Фактори, які формують загрозу & Наслідки \\
\hline $\begin{array}{l}1 \text { Втрати традиційних ринків збуту сільськогоспо- } \\
\text { дарської сировини. }\end{array}$ & $\begin{array}{l}\text { Економічні втрати держави і виробників сільгосппроду- } \\
\text { кції, зменшення ефективності аграрного сектору. }\end{array}$ \\
\hline $\begin{array}{l}\text { 2. Зниження цін на окремі товари українського } \\
\text { експорту та підвищення цін на експортне продово- } \\
\text { льство. }\end{array}$ & $\begin{array}{l}\text { Сприяє відпливу сировини із країн та погіршенню спо- } \\
\text { живання продуктів населення. }\end{array}$ \\
\hline 3. Низька якість імпортованих харчових продуктів. & $\begin{array}{l}\text { Посилює екологічну напруженість, } є \text { загрозою для здо- } \\
\text { ров'я. }\end{array}$ \\
\hline $\begin{array}{l}\text { 4. Розширення виробництва біопалива із сільсько- } \\
\text { господарської продукції та сировини. }\end{array}$ & $\begin{array}{l}\text { Зменшує площі посіву с/г культур, передбачених на } \\
\text { споживання населенням, зазнає витрат родючості грун- } \\
\text { ту. }\end{array}$ \\
\hline $\begin{array}{l}\text { 5. Використання організаційних та економічних } \\
\text { важелів } 3 \text { виробництва сільськогосподарської про- } \\
\text { дукції. }\end{array}$ & $\begin{array}{l}\text { Створюються штучні бар'єри для експорту вітчизняної } \\
\text { продукції, порушується баланс по окремим видам про- } \\
\text { довольства. }\end{array}$ \\
\hline $\begin{array}{l}\text { 6. Використання різних програм та субсидій для } \\
\text { розширення експорту розвиненими країнами та } \\
\text { формування ними агресивної експортної політики. }\end{array}$ & $\begin{array}{l}\text { Призводить до не добросовісної конкуренції, підвищує } \\
\text { зростання імпорту. }\end{array}$ \\
\hline $\begin{array}{l}\text { 7. Входження до міжнародних торгівельно- еконо- } \\
\text { мічних зон та організацій. }\end{array}$ & $\begin{array}{l}\text { Дотримання міжнародних угод і зобов’язань, не завжди } \\
\text { вигідних для вітчизняних виробників. }\end{array}$ \\
\hline
\end{tabular}

Таблиця 2

Внутрішні загрози продовольчої безпеки [9]

\begin{tabular}{|l|l|}
\hline \multicolumn{1}{|c|}{ Фактори, які формують загрозу } & \multicolumn{1}{|c|}{ Наслідки } \\
\hline $\begin{array}{l}\text { 1. Низькі темпи підвищення рівня життя населення, } \\
\text { відставання рівня життя від відповідних показників } \\
\text { у розвинених країнах. }\end{array}$ & $\begin{array}{l}\text { Гальмує розвиток людського потенціалу, може призве- } \\
\text { сти до соціального напруження, відплив робочої сили з } \\
\text { села в місто. }\end{array}$ \\
\hline $\begin{array}{l}\text { 2. Низький рівень платоспроможності попиту на } \\
\text { продукти харчування переважної більшості насе- } \\
\text { лення. }\end{array}$ & Призводить до незбалансованого харчування. \\
\hline
\end{tabular}


Продовження таблиці 2

3. Незадовільна матеріально-технічна база, низька технологічна та технічна оснащеність сільськогосподарського виробництва.

4. Посилення залежності по окремих видах харчових продуктів від їх імпорту.

5. Низький рівень впровадження інновацій, принципово нових розробок «ноу-хау» у сільському господарстві

6. Слабка інформаційна база, яка не дозволяє правильно оцінити резерви і можливості

7. Дефіцит кваліфікованих кадрів, низький рівень знать АПК міжнародних правил торгівлі

8. Недостатній досвід активного захисту регіональних інтересів у національних стосунках та 3 міжнародними організаціями.

9. Криза платежів та не ефективність фінансового, податкового та страхового регулювання.

10. Недостатній контроль 3 боку держави і суспільних організацій над безпекою та якістю продуктів

11. Відсутність дієвого механізму ціноутворення АПК, диспаритет цін на сировину, засоби виробництва, готову продукцію та послуги у відповідних видах діяльності.

12. Недостатність, не стабільність або відсутність нормативно-правової бази.

13. Недостатній рівень державної фінансової підтримки підприємств АПК

Залежно від рівня ієрархії внутрішні загрози поділяють на [10]:

- прогнозовані - це загрози, які можна легко передбачити та вчасно проводити заходи щодо їх профілактики і запобігання;

- не прогнозовані можуть виникати в результаті спаду агропромислового

виробництва в цілому, внаслідок впливу несприятливих природних умов (засухи, повені, вимерзання тощо), зумовлюють зниження врожайності, валових зборів та валового виробництва;

- керовані загрози не завдають значної шкоди продовольчій безпеці, адже нейтралізуються шляхом прямого впливу з боку апарату управління;

- некеровані загрози є більш небезпечними, оскільки не піддаються дії прямого впливу, а подіяти на них можна лише через припинення дії керованих загроз;
Збільшує втрати врожаю, знижує конкурентоспроможність сільськогосподарських товаровиробників.

Гальмує розвиток відповідних вітчизняних виробництв, відплив із країни валютних ресурсів, погіршує фінансовий стан країни.

Гальмує розвиток аграрного сектору, призводить до відставанню від світового науково-технічного прогресу

Веде до помилок при визначені оціночних рівнів економічної безпеки, стану галузі та напрямів оперативних заходів.

Гальмує інноваційно-технічний розвиток галузі, можливі втрати при проведені зовнішньоекономічної діяльності.

Погіршення іміджу, економічні витрати АПК.

Нестабільність фінансового стану підприємства галузі, імовірність ії банкрутства.

Підвищує загрозу здоров'ю нації.

Призводить до високих темпів зростання цін на продовольство, зниження економічного інтересу у сільського товаровиробника.

Посилює деструктивні тенденції у виробництві та споживанні

Сприяє збільшенню внутрішніх цін на вітчизняну продукцію, що перевищують світові.

- дисбалансуючі загрози не завдають продовольчій безпеці значної шкоди, оскільки легко відновлюють належний рівень продовольчої безпеки, на відміну від деструктивних, усунення яких потребує великих затрат часу та різного роду ресурсів (грошових, матеріальних, трудових).

Всі ці загрози дуже тісно пов'язані між собою і мають велике значення для країни, наприклад, незбалансоване споживання продуктів харчування населенням. Так, баланс споживання основних продуктів харчування (табл. 3) свідчить [5], що у 2014 р. в Україні за такими продовольчими групами, як: «хліб і хлібопродукти», «картопля», «олія рослинна всіх видів», «яйця» та «овочі та баштанні» фактичне споживання перевищило раціональну норму, але таке перевищення $є$ свідченням незбалансованості харчування населення, яке намагається забезпечити власні потреби за рахунок економічно доступніших продуктів.

Таблиця 3

Показник достатності споживання продуктів харчування (на особу на рік; кг) [5, 11]

\begin{tabular}{|l|l|l|l|}
\hline \multicolumn{1}{|c|}{ Продукти } & \multicolumn{1}{|c|}{$\begin{array}{c}\text { Раціональна } \\
\text { норма }\end{array}$} & $\begin{array}{c}\text { Фактичне } \\
\text { споживання у } \\
2014 \text { р. }\end{array}$ & $\begin{array}{c}\text { Показники } \\
\text { достатності } \\
\text { споживання }\end{array}$ \\
\hline Хліб і хлібопродукти & 101,0 & 108,4 & 1,07 \\
\hline М'ясо і м'ясопродукти & 80,0 & 56,1 & 0,70 \\
\hline
\end{tabular}


Продовження таблиці 3

\begin{tabular}{|l|l|l|l|}
\hline Молоко і молочні продукти & 380,0 & 220,9 & 0,58 \\
\hline Риба та рибопродукти & 20,0 & 14,6 & 0,73 \\
\hline Яйця (шт..) & 290,0 & 309,0 & 1,07 \\
\hline Овочі та баштанні & 161,1 & 163,3 & 1,01 \\
\hline Плоди, Ягоди та виноград & 90,0 & 56,3 & 0,63 \\
\hline Картопля & 124,0 & 135,4 & 1,09 \\
\hline Цукор & 38,0 & 37,1 & 0,98 \\
\hline Олія рослинна (всіх видів) & 13,0 & 13,3 & 1,02 \\
\hline
\end{tabular}

Помітним $є$ відставання від раціонального споживання за наступними групами: «молоко і молокопродукти» - на 42 \%, «плоди, ягоди і виноград»- на $37 \%$, «м'ясо і м'ясопродукти» - на $30 \%$, «риба та рибопродукти» - на 27 \%, «цукор» - на $2 \%$ [11].

Показники худоби та птиці за 1990-2015 рр. [12]

\begin{tabular}{|c|c|c|c|c|c|}
\hline \multirow{2}{*}{} & \multicolumn{5}{|c|}{ Поголів'я худоби та птиці на 1 січня, тис. голів } \\
\cline { 2 - 3 } & \multicolumn{2}{|c|}{ Велика рогата худоба } & $\begin{array}{c}\text { Свині, млн. } \\
\text { голів }\end{array}$ & $\begin{array}{c}\text { Вівці та кози, } \\
\text { млн голів }\end{array}$ & $\begin{array}{c}\text { Птиця, млн. } \\
\text { голів }\end{array}$ \\
\cline { 2 - 5 } & Усього & У т.ч. корови & 19946,7 & 9003,1 & 255,1 \\
\hline 1990 & 25194,8 & 8527,6 & 13945,5 & 5574,5 & 164,9 \\
\hline 19905 & 19624,3 & 7818,3 & 10072,9 & 1884,7 & 126,1 \\
\hline 2000 & 10626,5 & 5431 & 6466,1 & 1754,5 & 152,8 \\
\hline 2005 & 6902,9 & 3926 & 7576,6 & 1832,5 & 191,4 \\
\hline 2010 & 4826,7 & 2736,5 & 7922,2 & 1735,2 & 230,3 \\
\hline 2015 & 4534 & 2508,8 & 7350,7 & 1371,1 & 213,3 \\
\hline
\end{tabular}

Виходячи с даних табл. 4, спостерігається зниження поголів'я худоби порівнюючи 1990 рік2014 , ми бачимо, що поголів'я корів зменшилось на $3,5 \%$, свині на 2,5\%, вівці та кози зменшились на
5,2\%, птиця на 1,2 \%, що суттєво впливає на виробництво основних видів продуктів тваринництва (табл. $5)$.

Динаміка виробництва основних видів продукції тваринництва [12]

\begin{tabular}{|c|c|c|c|c|}
\hline \multirow{2}{*}{} & \multicolumn{3}{|c|}{ Виробницто основних видів продукції тваринницва } \\
\cline { 2 - 5 } & $\begin{array}{c}\text { м'ясо(у забійній } \\
\text { вазі) тис. т }\end{array}$ & молоко тис.т & $\begin{array}{c}\text { яйця від птиці, млн. } \\
\text { шт }\end{array}$ & вовна, т \\
\hline 1990 & 4357,8 & 24508,3 & 16286,7 & 29804 \\
\hline 1995 & 2293,7 & 17274,3 & $9403 . .5$ & 13926 \\
\hline 2000 & 1662,8 & 12657,9 & 8808,6 & 3400 \\
\hline 2005 & 1597 & 13714,4 & 13045,9 & 3195 \\
\hline 2010 & 2059 & 11248,5 & 17052,3 & 4192 \\
\hline 2013 & 2389,4 & 11488,2 & 19614,8 & 3520 \\
\hline
\end{tabular}

Так, дані свідчать, що порівнявши 1990 i 2013 рр. виробництво м’яса зменшилось на 1,8\%, молока приблизно на 2,2\%, кількість яєць виросла на $1,2 \%$, бавовни зменшилось на $8,4 \%$.

До суттєвих загроз відноситься й незбалансований експорт та імпорт України. Так, розглядаючи дані про структуру валового внутрішнього продукту

України (табл. 6) за кінцевим використанням можна побачити динаміку співвідношення експорту та імпорту України за останні роки з 2005-2014 р., яка показує, що вивіз товару з території України перевищує імпортну продукцію і це означає, що торгівельний баланс України пасивній. Якщо взяти данні за 2005 рік, то ми бачимо, що \% сальдо ВВП склав: $+0,8 \%$, а $з 2006$ по 2014p, ми спостерігаємо дуже низький рівень \%сальдо ВВП, який коливається від $1,7 \%$ до $-8,5 \%$.

Ми вважаємо, що це велика проблема, яка посилює й екологічну напруженість нашої країни і виступає великою загрозою для України. 
Таблиця 6

Зовнішньоторговельний баланс України [12]

\begin{tabular}{|c|c|c|c|c|c|c|c|}
\hline \multirow{2}{*}{ Роки } & \multirow{2}{*}{$\begin{array}{c}\text { Номінальний } \\
\text { ВВП }\end{array}$} & \multicolumn{2}{|c|}{ Експорт } & \multicolumn{2}{c|}{ Імпорт } & \multicolumn{2}{c|}{$\begin{array}{c}\text { Сальдо } \\
\text { (експорт-імпорт) }\end{array}$} \\
\cline { 3 - 8 } & & $\begin{array}{c}\text { Товарів в } \\
\text { млн. грн }\end{array}$ & $\%$ \%ВП & $\begin{array}{c}\text { Товарів в } \\
\text { млн.. грн }\end{array}$ & $\%$ ВВП & $\begin{array}{c}\text { Товарів в } \\
\text { млн.. грн }\end{array}$ & $\%$ ВВП \\
\hline 2005 & 441452 & 227252 & $51,5 \%$ & -223555 & $-50,6 \%$ & +3697 & $+0,8 \%$ \\
\hline 2006 & 544153 & 253707 & $46.6 \%$ & -269200 & $-49,5 \%$ & -15493 & $-2,8 \%$ \\
\hline 2007 & 720731 & 323205 & $44,8 \%$ & -364373 & $-50,6 \%$ & -41168 & $-5,7 \%$ \\
\hline 2008 & 948056 & 444859 & $46,9 \%$ & -520588 & $-54,9 \%$ & -75729 & $-8,0 \%$ \\
\hline 2009 & 913345 & 423564 & $46,4 \%$ & -438860 & $-48,0 \%$ & -15296 & $-1,7 \%$ \\
\hline 2010 & 1082569 & 549365 & $50,7 \%$ & -580944 & $-53,7 \%$ & -31579 & $-2,9 \%$ \\
\hline 2011 & 1316600 & 707953 & $53,8 \%$ & -779028 & $-59,2 \%$ & -71075 & $-5,4 \%$ \\
\hline 2012 & 1408889 & 717347 & $50,9 \%$ & -835394 & $-59,3 \%$ & -118047 & $-8,4 \%$ \\
\hline 2013 & 1454931 & 681899 & $46,9 \%$ & -805662 & $-55,4 \%$ & -123763 & $-8,5 \%$ \\
\hline 2014 & 1566728 & 770121 & $49,2 \%$ & -834133 & $-53,2 \%$ & -64012 & $-4,1 \%$ \\
\hline
\end{tabular}

3 метою мінімізації загроз продовольчої безпеки держави, забезпечення доступності, якості та безпечності продовольства для усіх верств населення, на нашу думку, Кабінету Міністрів України, Міністерству аграрної політики та продовольства необхідно:

- відновлювати і розвивати вітчизняне виробництво продуктів харчування та сировини. Проте все ж обов'язково контролювати підтримання фізичної та економічної доступності безпечних продуктів харчування згідно з нормам [13];

- слід створити комплексну систему спостережень, збору, обробки, систематизації та аналізу інформації щодо виробництва, управління запасами і постачання продовольства, якості і безпеки харчових продуктів, споживання продовольства та харчування населення [14];

- виробництво екологічно чистої сільськогосподарської продукції дасть можливість зменшити шкідливий вплив на здоров'я людини і покращити якість життя, що також буде покращувати демографічну ситуацію в країні [15];

- підвищення родючості земель сільськогосподарського призначення і урожайності сільськогосподарських культур, розвиток тваринництва і його кормової бази [16];

- розробити та забезпечити впровадження у правове поле законодавчого акту «Про продовольчу безпеку», у якому визначатимуться правові, економічні, соціальні, екологічні та організаційні основи діяльності держави, спрямованої на захист національних інтересів і гарантування в Україні продовольчої безпеки особи, суспільства і держави від зовнішніх і внутрішніх загроз та встановлюватиметься відповідальність держави за належний рівень харчування населення;
- розробити і запровадити програми продовольчого субсидування населення, які включатимуть надання адресних дотацій малозабезпеченим верствам населення, організацію мереж соціального харчування для організації раціонального харчування найбільш незахищених верств населення, забезпечення харчування дітей раннього, дошкільного та шкільного віку через державні контракти на постачання харчових продуктів [17].

Висновки та перспективи подальших досліджень.

Сільськогосподарський аспект показує використання аграрного потенціалу країни у виробництві необхідних обсягів сільськогосподарської сировини та продовольства і характеризується відповідними показниками ефективності сільського господарства: урожайності культур, продуктивності тварин, продуктивності сільськогосподарських угідь, продуктивності праці, рентабельності виробництва, фондовіддачі.

3 огляду на проведене дослідження та українські реалії, ми згодні [18], що продовольча безпека це такий рівень продовольчого забезпечення населення, який гарантує соціально-політичну стабільність у суспільстві, виживання і розвиток нації, особи, сім'ї, стійкий економічний розвиток держави. На нашу думку, ситуацію, яка склалась в сільському господарстві, можна назвати критичною: на сьогодні у великих містах 60-70\% продовольства забезпечується за рахунок імпорту і для України такий стан $є$ жахливим, а позбавлення від імпортної залежності передбачає потужну програму розвитку власного сільського господарства. Таким чином, продовольча безпека - це такий рівень продовольчого забезпечення населення, який гарантує соціально-політичну стабільність у суспільстві, виживання і розвиток нації, особи, сім'ї, стійкий економічний розвиток держави. 


\section{Література}

1. Линник О.І. Проблеми зовнішніх та внутрішніх факторів / О.І. Линник, Н.В. Артеменко: Електронний ресурс. - Режим доступу: www.kpi.kharkov. ua/archive/Наукова_періодика/vestnik/Технічний\%20прогрес\%20та\%20 ефективність\%20виробництва/2013/44/ВПЛИВ\%203ОВНІШНІХ\%20ТА\%20ВНУТРІШНІХ\%203АГРОЗ\%20НА\%2 0ФОРМУВАННЯ\%20СИСТЕМИ\%20ЕКОНОМІЧНОЇ\%20БЕЗПЕКИ\%20ПІДПРИСМСВА.pdf.

2. Гойчук О.І. Продовольча безпека:. Монографія / О.І. Гойчук. - Житомир: Полісся, 2004. 348-359 c.

3. Ульянченко О.В.. Продовольча безпека - основа національної безпеки держави / О.В. Ульнченко О. В.: Електронний ресурс. - Режим доступу: http://humanright.org.ua/blogs/prodovolcha_bezpeka.

4. Кочетков О.В. Формування системи показників продовольчої безпеки України/ О.В. Кочетков, Р.В. Марков // Економіка АПК. - 2002. - № 9. - С.142-158.

5. Ульянченко.В. Продовольча безпека - основа національної безпеки держави / О. В. Ульянченко Н.В. Прозорова: Електронний ресурс. - Режим доступу:

http://congressworld.com.ua/blog_article.php?id=5.

6. Загроза - шо це таке?: Електронний ресурс. - Режим доступу: http://www. naiau.kiev.ua/books/mnp_krum_pravo_zag/Files/Lekc/T7/T7_P2.htm

7. Україна. Закон. Про продовольчу безпеку України. Розділ 1: ЗАГАЛЬНІ ПОЛОЖЕННЯ.; Стаття 1 Терміни та їх визначення: Електронний ресурс. - Режим доступу: http://mediku.com.ua/zakon-ukrayini-pro-prodovolechu-bezpeku-ukrayini.html.

8. Паліга Н.Б. Шляхи запобігання зовнішнім та внутрішнім загрозам економічній безпеці промислового підприємства / Н.Б. Паліга, Ю.В. Світлична // Економіка промисловості: Електронний ресурс. Режим доступу: http://www.nbuv.gov.ua/old_jrn/soc_gum/eprom/2011_53/st_53_30.pdf.

9. Чехович Г.Т. Методичні підходи до оцінки економічної безпеки країни та регіонів / Г.Т. Чехович // Ефективна економіка: Електронний ресурс. - Режим доступу:

http://www.economy.nayka.com.ua/?p=195\&w=\&op=8.

10. Линник О.І.. Вплив зовнішніх та внутрішніх загроз на формування системи економічної безпеки підприємства / О.І. Линник, Н.В. Артеменко // Вісник НТУ «ХПІ». - 2013. - №44/1017: Електронний ресурс. - Режим доступу:

http://www.kpi.kharkov.ua/archive/Наукова_періодика/vestnik/Технічний\%20прогрес\%20та\%20ефективність \%20виробництва/2013/44/ВПЛИВ\%203ОВНІШНІХ\%20ТА\%20ВНУТРІШНІХ\%203АГРОЗ\%20НА\%20ФО РМУВАННЯ\%20СИСТЕМИ\%20ЕКОНОМІЧНОЇ\%20БЕЗПЕКИ\%20ПІДПРИЄМСВА.pdf.

11. Русан В.М.. Відділ безпеки реального сектору економіки: Електронний ресурс. - Режим доступу: http://www.niss.gov.ua/public/File/2015_analit/ prodovolcha_bezpeka.pdf.

12. Державна служба статистики України в період с 2005-2014pp.: Електронний ресурс. - Режим доступу: http://www.ukrstat.gov.ua.

13. Сідоренко. Продовольча безпека України не можлива без державного регулювання АПК / О. Сідоренко // Економіст: Електронний ресурс. - Режим доступу: http://ua-ekonomist.com/216-prodovolchabezpeka-ukrayini-nemozhliva-bez-derzhavnogo-regulyuvannya-apk.html.

14. Дейнеко Л.В. Стратегічні пріоритети та сучасні завдання розвитку реального сектору економіки України / Дейнеко Л.В., Сичевський М.П., Шелудько Е.І., Коваленко А.О. та ін. - 2007: Електронний peсурс. - Режим доступу: https://books.google.com.ua/books?id=v3XYAwAAQBAJ\&pg=PA353 $\& l p g=P A 353 \& d q$.

15. Мельник Л.Г. Основи екології. Екологічна економіка та управління природокористуванням: Підручник / Л.Г. Мельник. - Суми: ВТД «Університетська книга», 2005. - 759 с.

16. Біла С.О. Продовольча безпека в системі економічної безпеки / С.О. Біла // Держава та регіони. Серія: Державне управління. - 2008. - №1. - С.15-20.

17. Сучасний сан та загрозі продовольчій безпеці України: Електронний ресурс. - Режим доступу: http://www.niss.gov.ua/public/File/2015_analit/prodovolcha_bezpeka.pdf.

18. Методичні рекомендації щодо розрахунку рівня економічної безпеки України / затверджені Наказом Міністерства економічного розвитку і торгівлі України від 29.10.2013 р. № 1277: Електронний ресурс. - режим доступу: http://www.me.gov.ua/Documents/List?lang=uk-UA\&tag= MetodichniRekomendatsii. 


\author{
Руммо В.В. \\ кандидат экономических наук, доцент \\ кафедра економической теории \\ и финансово-економической безопасности \\ Одесская национальная академия пищевых технологий \\ ул. Канатная, 112, г. Одесса, Украина, 65039 \\ E-mail: etfeb@ukr.net \\ Рожнатова М.В. \\ аналитик по экономическим вопросам ТОВ «Шабо» \\ Французский бульвар, 66/2, г.Одесса, Украина, 65044 \\ E-mail: rozhnatovamarina@mail.ru
}

\title{
ВНЕШНИЕ И ВНУТРЕННИЕ УГРОЗЫ ПРОДОВОЛЬСТВЕННОЙ БЕЗОПАСНОСТИ
}

\begin{abstract}
В статье выделены внутренние и внешние угрозы продовольственной безопасности Украины и предложены направления обеспечения продовольственной безопасности страны. Охарактеризованы основные угрозы продовольственной безопасности Украины, определены особенности их влияния. Целью статьи является исследование аспектов внутренних и внешних угроз продовольственной безопасности в трудах ученых и выделение их в целях совершенствования методов диагностики внешних и внутренних угроз продовольственной безопасности, обоснования направлений дальнейших исследований.
\end{abstract}

Продукты питания важны и незаменимы в жизнедеятельности человека, поэтому развитие пищевой промышленности и производства сельскохозяйственной продукции является основой питания, выступает демографическим фактором., который является основным для обеспечения естественных потребностей человека, поэтому изучение проблем продовольственной безопасности имеет всегда значимую актуальность. Исследование показало, что продовольственная безопасность - это такой уровень продовольственного обеспечения населения, который гарантирует социальнополитическую стабильность в обществе, выживание и развитие нации, личности, семьи, устойчивое экономическое развитие государства. Продовольственная безопасность имеет национальный характер, ей присуща комплексность и перманентность. В зависимости от особенностей национальной продовольственной системы, периода ее развития, от того, какая составляющая продовольственной проблемы набирать на том или ином этапе приоритетное значение, задачи ее обеспечения модифицируются вместе с изменениями внутренних и внешних угроз.

С целью минимизации угроз продовольственной безопасности государства, обеспечения доступности, качества и безопасности продовольствия для всех слоев населения, Кабинета Министров Украины, Министерству аграрной политики и продовольствия предложены меры ее обеспечения.

Ключевые слова: продовольственная безопасность, угроза, внутренние угрозы, внешние угрозы, государственное регулирование.

\author{
Rummo V. \\ Ph.D. in Economics, Associate Professor \\ Department of Economic Theory \\ financial and economic security \\ Odessa National Academy of Food Technologies \\ Kanatna str., 112 , Odessa, Ukraine, 65039 \\ E-mail: etfeb@ukr.net \\ Roznatova M. \\ Analyst by the economic questions of LLC "Shabo" \\ Frantsuzskiy boulevard, 66/2, Odessa, Ukraine, 65044 \\ E-mail: rozhnatovamarina@mail.ru
}

\section{EXTERNAL AND INTERNAL THREATS OF FOOD SECURITY}

In article internal and external threats of food security of Ukraine are allocated and the directions of ensuring food security of the country are offered. The main threats of food security of Ukraine are character rized, features of their influence are determined. The purpose of article is research of aspects of internal and external threats of food security in works of scientists and their allocation for the purpose of enhancement of methods of diagnostics of external and internal threats of food security, reasons for the directions of further researches. 
Food are important and irreplaceable in activity of the person therefore development of the food industry and production of agricultural products is a food basis, acts as demographic factor., which is the basic for ensuring needs of nature of the person therefore studying of problems of food security has always significant relevance. Research has shown that the food security is the such level of food supply of the population which guarantees socio-political stability in society, a survival and development of the nation, the personality, a family, sustainable economic development of the state. The food security has national nature, complexity and permanence is inherent in it. Depending on features of national food system, the period of its development, from what component of a food problem to gain priority value at this or that stage, tasks of its providing are modified together with changes of internal and external threats.

For the purpose of minimization of threats of food security of the state, ensuring availability, quality and safety of the food for all segments of the population, Cabinet council of Ukraine, to the Ministry of an agrarian policy and the food measures of its providing are proposed.

Keywords: food security, threat, internal threats, external threats, state regulation.

\section{References}

1. Lynnyk, O. I., \& Artemenko, N. V. (n.d.). Problemy zovnishnikh ta vnutrishnikh faktoriv. Retrieved from www.kpi.kharkov. ua/archive/Naukova_ periody-ka/vestnik/Tekhnichnyi prohres ta efektyv-nist vyrobnytstva/2013/44/VPLYV ZOVNIShNIKh TA VNUTRIShNIKh ZAHROZ NA FORMUVANNIa SYSTEMY EKONOMIChNOI BEZPEKY PIDPRYIeMSVA.pdf.

2. Hoichuk, O. I. (2004). Prodovolcha bezpek. Zhytomyr: Polissia.

3. Ulnchenko, O. V. (n.d.). Prodovolcha bezpeka - osnova natsionalnoi bezpeky derzhavy. Retrieved from http://humanright.org.ua/blogs/prodovolcha_bezpeka.

4. Kochetkov, O. V., \& Markov, R. V. (2002). Formuvannia systemy pokaznykiv prodovolchoi bezpeky Ukrainy. Ekonomika APK, 9, 142-158.

5. Ulianchenko, O. V., \& Prozorova, N. V. Prodovolcha bezpeka - osnova natsionalnoi bezpeky derzhavy. Retrieved from http://congressworld.com.ua/blog_article.php?id=5.
6. Zahroza
sho tse take?
(n.d.).
Retrieved
from
http://www.

naiau.kiev.ua/books/mnp_krum_pravo_zag/Files/Lekc/T7/T7_P2.htm

7. Ukraina. Zakon. Pro prodovolchu bezpeku Ukrainy. Rozdil 1: ZAHALNI POLOZhENNIa.; Stat-tia 1 Terminy ta yikh vyznachennia. (n.d.). Retrieved from http://mediku.com.ua/zakon-ukrayini--pro-prodovolechu-bezpekuukrayini.html.

8. Paliha, N. B., \& Svitlychna, I. V. Shliakhy zapobihannia zovnishnim ta vnutrishnim zahrozam ekonomichnii bezpetsi promyslovoho pidpryiemstva. Retrieved from http://www.nbuv.gov.ua/old_jrn/soc_gum/eprom/2011_53/st _53_30.pdf

9. Chekhovych, H. T. Metodychni pidkhody do otsinky ekonomichnoi bezpeky krainy ta rehioniv. Retrieved from http://www.economy.nayka.com.ua/?p=195\&w=\&op=8

10. Lynnyk,, O. I., \& Artemenko, N. V. (2013). Vplyv zovnishnikh ta vnutrishnikh zahroz na formuvannia systemy ekonomichnoi bezpeky pidpryiemstva. $\quad$ Retrieved from http://www.kpi.kharkov.ua/archive/Naukova_periodyka/vestnik/Tekhnichnyi prohres ta efektyvnist vyrobnytstva/2013/44/VPLYV ZOVNIShNIKh TA VNUTRIShNIKh ZAHROZ NA FORMUVANNIa SYSTEMY EKONOMIChNOI BEZPEKY PIDPRYIeMSVA.pdf.

11. Rusan, V. M. Viddil bezpeky realnoho sektoru ekonomiky. Retrieved from http://www.niss.gov.ua/public/File/2015_analit/prodovolcha_bezpeka.pdf.

12. Derzhavna sluzhba statystyky Ukrainy $\vec{v}$ period s 2005-2014rr. (n.d.). Retrieved from http://www.ukrstat.gov.ua.

13. Sidorenko, O. Prodovolcha bezpeka Ukrainy ne mozhlyva bez derzhavnoho rehuliuvannia APK. Retrieved from http://ua-ekonomist.com/216-prodovolcha-bezpeka-ukrayini-nemozhliva-bez-derzhavnogo-regulyuvannyaapk.html.

14. Deineko, L. V., Sychevskyi, M. P., Sheludko, E. I., \& Kovalenko, A. O. (2007). Stratehichni priorytety ta suchasni zavdannia rozvytku realnoho sektoru ekonomiky Ukrainy. Retrieved from https://books.google.com.ua/books?id=v3XYAwAAQBAJ\&pg=PA353 \&lpg=PA353\&dq.

15. Melnyk, L. H. (2005.). Osnovy ekolohii. Ekolohichna ekonomika ta upravlinnia pryrodokorystuvanniam. Sumy: VTD «Universytetska knyha».

16. Bila, S. O. (2008). Prodovolcha bezpeka v systemi ekonomichnoi bezpeky. Derzhava Ta Rehiony. Seriia: Derzhavne Upravlinnia, 1, 15-20.

17. Suchasnyi san ta zahrozi prodovolchii bezpetsi http://www.niss.gov.ua/public/File/2015_analit/prodovolcha_bezpeka.pdf.

18. Metodychni rekomendatsii shchodo rozrakhunku rivnia ekonomichnoi bezpeky Ukrainy / zatverdzheni Nakazom Ministerstva ekonomichnoho rozvytku i torhivli Ukrainy vid 29.10.2013 r. № 1277. (2013). Retrieved from http://www.me.gov.ua/Documents/List?lang=uk-UA\&tag= Metodich 